\title{
Analisa Penumpang dengan Metode SARIMA (Studi Kasus: Bandar Udara Raja Haji Fisabilillah)
}

\author{
Yayuk Setyaning Astutik ${ }^{1}$ \\ ${ }^{1}$ Universitas Internasional Batam, yayuk@uib.ac.id
}

\begin{abstract}
Raja Haji Fisabilillah International Airport is an airport in Tanjungpinang and it is quite high in service levels for the flow of passengers and goods. Based on the data from Airport Quality Angkasa Pura II, the passengers growth has both decreased and increased in the last 3 (three) years. In 2015 , there were 258,936 people in total and has decreased to 246,828 people in 2016 and increased again in 2017 by 351,688 people. Therefore, it is necessary to evaluate the terminal of Raja Haji Fisabilillah International Airport. The methods used are observation and forecasting using the SARIMA. The evaluation and analysis results show that the terminal of Raja Haji Fisabilillah International Airport still meets the applicable standards and passenger movements for the next year 2020 indicate that all equipment facilities for the needs of terminal passengers of Raja Haji Fisabilillah International Airport are still adequate.
\end{abstract}

Keywords: SARIMA, Forecasting, Passenger, Airport.

\begin{abstract}
Abstrak. Bandar Udara Internasional Raja Haji Fisabilillah merupakan bandar udara yang ada di Kota Tanjungpinang dan merupakan bandara yang cukup tinggi dalam tingkat pelayanan terhadap arus penumpang maupun barang. Berdasarkan data dari Airport Quality Angkasa Pura II bahwa pertumbuhan penumpang mengalami penurunan dan peningkatan dalam 3 (tiga) tahun terakhir, tercatat data tahun 2015 sebanyak 258.936 orang, tahun 2016 menurun menjadi 246.828 orang dan meningkat kembali di tahun 2017 sebanyak 351.688 orang. Oleh karena itu, perlu dilakukan evaluasi terhadap terminal penumpang Bandar Udara Internasional Raja Haji Fisabilillah. Metode yang digunakan ialah observasi dan peramalan menggunakan SARIMA. Hasil evaluasi dan analisis menunjukkan bahwa terminal penumpang Bandar Udara Internasional Raja Haji Fisabilillah masih memenuhi standar dan syarat yang berlaku dan pergerakan penumpang untuk tahun mendatang 2020 menunjukkan seluruh fasilitas peralatan pelayanan kebutuhan terminal penumpang Bandar Udara Internasional Raja Haji Fisabilillah masih memadai .
\end{abstract}

Katakunci: SARIMA, Peramalan, Penumpang, Bandara.

\section{Latar Belakang}

Tanjungpinang memiliki bandar udara yang bernama Bandar Udara Internasional Raja Haji Fisabilillah. Bandar udara ini merupakan bandara yang cukup tinggi dalam tingkat pelayanan terhadap arus penumpang maupun barang. Berdasarkan data dari Airport Quality Angkasa Pura II bahwa pertumbuhan penumpang mengalami penurunan dan peningkatan dalam 3 (tiga) tahun terakhir, tercatat data tahun 2015 sebanyak 258.936 orang, tahun 2016 menurun menjadi 246.828 orang dan meningkat kembali di tahun 2017 sebanyak 351.688 orang. Keterbatasan fasilitas peralatan pelayanan di terminal keberangkatan akan mengakibatkan jumlah antrian penumpang menunggu proses pelayanan sehingga terjadi penumpukan. Oleh karena itu, perlu adanya dilakukan evaluasi terhadap terminal penumpang Bandar Udara Internasional Raja Haji Fisabilillah Tanjungpinang agar dapat dijadikan patokan untuk pembangunan bandar udara pada masa yang akan datang serta sebagai tolak ukur untuk mengetahui keadaan 
saat ini apakah bandar udara tersebut masih bekerja dengan efektif atau sudah melebihi kapasitas yang telah diperizinkan (Overload). Tujuan penulisan penelitian ini adalah untuk Memprediksi jumlah pergerakan penumpang tahun mendatang ${ }^{[4]}$. Peneliti membatasi masalah Analisa Penumpang Bandar Udara Raja Haji Fisabilillah dengan Metode SARIMA.

\section{Kerangka Teoritis}

\subsection{Penelitian Terdahulu}

Kajian kinerja pada Terminal Penumpang Bandar Udara Kelas I Utama Juwata Tarakan, karena diberlakukannya peraturan Kemenhub No. PM 157 pada tahun 2015, kajian tersebut menerapkan metode Importance Performance Analysis (IPA), Quality Function Deployment (QFD) dan Analisis Regresi Berganda. Dari hasil IPA diketahui tingkat kinerja pelayanan yang masih perlu ditingkatkan adalah waktu tunggu pemeriksaan memasuki ruang tunggu keberangkatan, rambu petunjuk dalam terminal, informasi angkutan lanjutan setelah turun dari pesawat, perawatan balita dan ruang menyusui, ketersediaan wifi/internet, fasilitas pembelian tiket online, jumlah tempat duduk di ruang keberangkatan, luas ruang tunggu keberangkatan dan luas ruang gerak penumpang ${ }^{[1]}$.

Evaluasi Konsep Desain Terminal Penumpang Bandara New Yogyakarta International Airport (NYIA) dikarena bandara ini di desain dengan 2 desain yang berbeda. Studi ini dilakukan dengan forecasting menggunakan metode peramalan ARIMA dan Triple Exponential Smoothing. Hasilnya menunjukkan jumlah penumpang Bandara Adisucipto Yogyakarta pada tahun 2017-2040 mengalami peningkatan rata-rata sebesar $7.90 \%$ setiap tahunnya, dan diketahui bahwa desain terminal pier lebih efisien dibandingkan dengan linear, karena terminal pier memiliki moving walkways yang lebih sedikit serta jarak jalan yang lebih pendek $210 \mathrm{~m}$ dibandingkan dengan desain terminal linear. Selain itu, hasil analisis nilai LOS diketahui bahwa hingga tahun 2031 terdapat 4 fasilitas terminal penumpang bandara yang memiliki nilai LOS di bawah C. Sehingga, pada tahun 2031 desain linear sudah tidak sesuai untuk Bandara NYIA maka pada tahun tersebut perlu dilakukan pengembangan desain terminal ${ }^{[2]}$.

Kapasitas dan Tingkat Pelayanan Terminal Penumpang Bandar Udara Ahmad Yani menggunakan metode survei dan observasi. Untuk evaluasi kinerja pelayanan dilakukan perhitungan waktu pelayanan berdasarkan tingkat kedatangan penumpang pada check-in counter dan baggage claim area, data yang didapat diolah menggunakan teori antrian kemudian hasilnya dibandingkan dengan standar yang ada pada PM. 178 Tahun 2015. Untuk evaluasi kapasitas melakukan analisis luasan terminal yang meliputi check-in area, ruang tunggu keberangkatan domestik, serta baggage claim area berdasarkan data penumpang yang diperoleh dari pihak bandara dengan menggunakan SNI 03-7046-2004, kemudian dilakukan forecasting untuk tahun 2022 menggunakan metode Arithmatic Straight Line Method. Hasil analisis menunjukkan waktu pelayanan pada check-in counter kurang dari 2,5 menit dan waktu pelayanan pada baggage claim area kurang dari 20 menit. Untuk luasan diperoleh luas check-in area sebesar $255 \mathrm{~m}^{2}$, luas ruang tunggu keberangkatan $1.485 \mathrm{~m}^{2}$ dan luas baggage claim area 894,96 $\mathrm{m}^{2}$, dari perhitungan forecasting untuk tahun 2022 didapat jumlah penumpang sebanyak 
5.321.414 penumpang dengan luas check-in area sebesar $1.350 \mathrm{~m}^{2}$, luas ruang tunggu keberangkatan $7.967 \mathrm{~m}^{2}$ dan luas baggage claim area $4.889 \mathrm{~m}^{2[3]}$.

Berdasarkan hasil perhitungan yang dilakukan, menunjukkan bahwa Terminal Penumpang Bandar Udara Internasional Raja Haji Fisabilillah Tanjungpinang masih sangat baik dalam memenuhi kebutuhan pergerakan penumpang pada jam sibuk serta masih memenuhi standar dan syarat yang berlaku sesuai SNI 03-70462004. Tetapi, dengan mengacu pada hasil forecasting diharapkan adanya pengembangan Bandar Udara Raja Haji Fisabilillah guna melayani jumlah penumpang yang akan semakin bertambah, khususnya pada bagian check-in counter dengan hasil perhitungan menggunakan metode SNI maupun metode FIFO dengan waktu pelayanan maksimum adalah 11 counter dan yang ada pada kondisi eksisting adalah 11 counter $^{[4]}$.

\subsection{Metode Seasonal Autoregressive Integrated Moving Average (SARIMA)}

\section{a. Proses Moving Average (MA) Musiman}

Bentuk umum dari proses Moving Average Musiman periode $S$ dengan tingkat $Q$ atau $M A(Q)^{S}$ didefinisikan sebagai berikut:

$X_{t}=e_{t}-\theta_{1} e_{t-S}-\theta_{2} e_{t-2 S}-\ldots-\theta_{Q} e_{t-Q S}$

dimana $e_{t}$ bersifat saling bebas terhadap $X_{t-1}, X_{t-2}, \ldots$ yang berdistribusi normal dengan mean 0 dan varian $\sigma^{2}$. Sebagai contoh dari model $M A(Q)^{S}$ akan dijelaskan dalam model $M A(1)^{12}$. Suatu proses $X_{t}$ dikatakan mengikuti $M A(1)^{12}$ jika $X_{t}$ mengikuti model:

$X_{t}=e_{t}-\theta_{1} e_{t-12}$

\section{b. Proses Autoregressive (AR) Musiman}

Bentuk umum dari proses Autoregressive musiman periode $S$ tingkat $P$ atau $A R(P)^{S}$ didefinisikan sebagai:

$X_{t}=\phi_{1} X_{t-S}+\phi_{2} X_{t-2 S}+\ldots+\phi_{P} X_{t-P S}+e_{t}$

Dimana $e_{t}$ bersifat saling bebas $X_{t-1}, X_{t-2}, \ldots$ yang berdistribusi normal dengan mean 0 dan varian $\sigma^{2}$. Sehingga contoh dari model $A R(P)^{S}$ akan dijelaskan dalam model $A R(1)^{12}$. Suatu proses $X_{t}$ dikatakan mengikuti $A R(1)^{12}$ jika $X_{t}$ mengikuti model

$X_{t}=\phi_{1} X_{t-12}+e_{t}$

\section{c. Model Seasonal ARIMA}

Musiman adalah kecenderungan mengulangi pola gerak dalam periode musim, biasanya satu tahun untuk data bulanan. Model ARIMA musiman merupakan model ARIMA yang digunakan untuk menyelesaikan time series musiman yang terdiri dari dua bagian, yaitu bagian tidak musiman (non-musiman) dan bagian musiman. Bagian non-musiman dari metode ini adalah model ARIMA. Secara umum bentuk model ARIMA musiman atau $\operatorname{ARIMA}(p, d, q)(P, Q, S)^{S}$ adalah: $\begin{array}{r}\phi_{p}(B) \Phi_{P}\left(B^{S}\right)(1-B)^{d}\left(1-B^{S}\right)^{D} X_{t} \\ =\theta_{q}(B) \Phi_{Q}\left(B^{S}\right) e_{r}\end{array}$ 


\section{Metodologi Penelitian}

\subsection{Jenis dan Sumber Data}

Data yang digunakan dalam penelitian ini merupakan data sekunder yaitu data dari Bandar Udara Raja Haji Fisabilillah, 2018.

\subsection{Metode Pengumpulan Data}

Pengumpulan data dilakukan dengan metode literature untuk mendukung referensi dan instrumen digunakan untuk pengambilan data yang berupa data jumlah penumpang di Bandar Udara Raja Haji Fisabillah.

\subsection{Metode Analisa dengan Metode SARIMA}

a. Proses identifikasi model.

b. Pendugaan parameter model.

c. Pemeriksaan residual (sisaan).

d. Penggunaan model untuk peramalan jika model memenuhi syarat.

\section{Analisa dan Pembahasan}

\subsection{Peramalan Data Time Series Musiman dengan Metode SARIMA}

Data yang digunakan dalam penerapan metode ini adalah data penumpang per tahun dari suatu maskapai penerbangan periode 2008-2019. Langkah pertama yang dilakukan adalah proses identifikasi model. Proses identifikasi model pertama kali diuji apakah data stasioner atau tidak dengan melihat plot asli data asli serta ACF dan PACF dari data asli. Time series plot untuk data tersebut adalah:

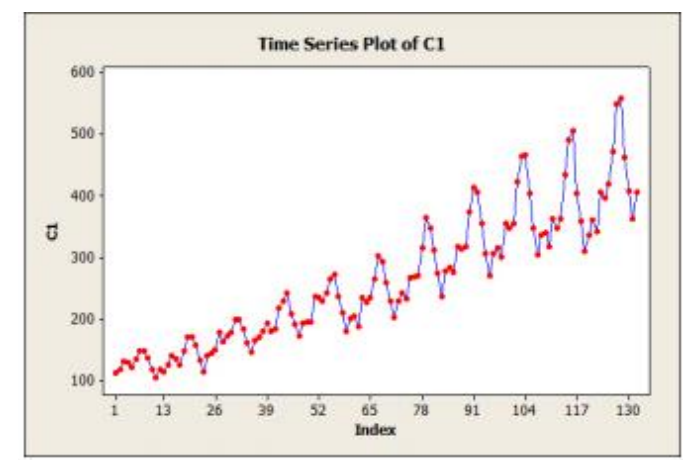

Gambar 1. Time Series dan Penumpang

Gambar 1 memperlihatkan bahwa data dipengaruhi pola trend sekaligus pola musiman karena plot menunjukkan fluktuasi meningkat, yaitu gerakan dari kiri bawah ke kanan atas pada grafik dan berulang pada bulan tertentu. Gambar 1 memperlihatkan bahwa pola trend sehingga pola trend tampak begitu tidak jelas. Gambar 2 dan Gambar 3 memperlihatkan terjadi autokorelasi pada data, yaitu adanya bar yang melebihi garis putus-putus sehingga data tidak stasioner. Oleh karena itu, data penumpang perlu di differencing untuk menstasionerkan data tersebut. 


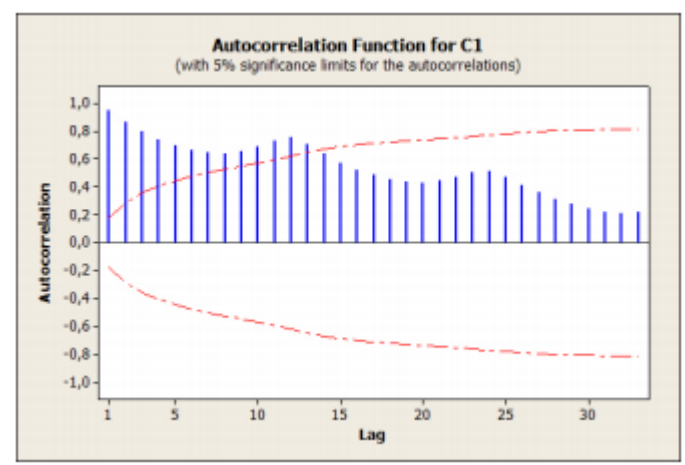

Gambar 2. Grafik ACF dari Penumpang

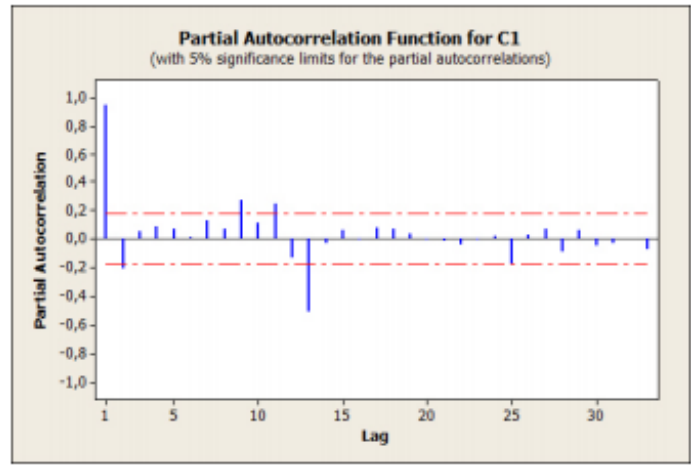

Gambar 3. Grafik PACF dari Penumpang

Gambar 4 merupakan plot data penumpang setelah dilakukan differencing pertama dan musiman lag 12. Dari plot tersebut terlihat bahwa data telah stasioner dalam rata-rata dan varian setelah differencing pertama dan musiman lag 12 karena fluktuasi datanya horizontal sepanjang sumbu waktu dan berarti nilai $d=1, D=12$.

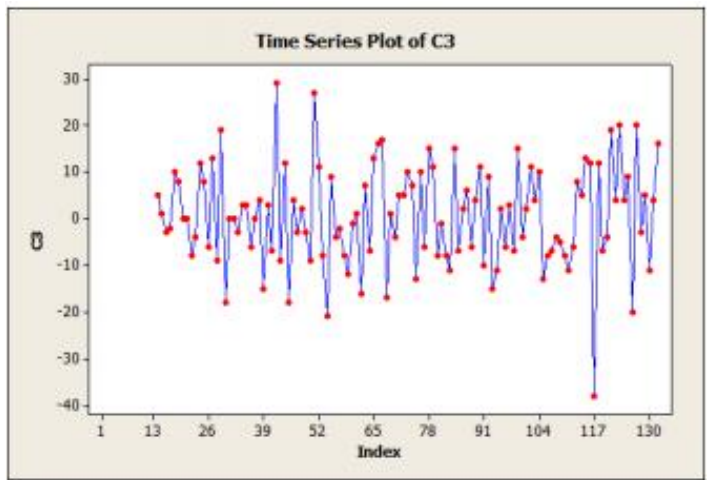

Gambar 4. Grafik differencing pertama dan Lag 12

Setelah dilakukan differencing dan musiman lag 12, tahap selanjutnya adalah pendugaan parameter model dengan menggunakan trial dan error yaitu menguji beberapa nilai yang berbeda. Pengdugaan parameter dapat dilakukan dengan melihat grafik ACF dan PACF data setelah dilakukan differencing pertama dan 
musiman lag 12. Gambar 5 dan Gambar 6 berikut merupakan grafik dari ACF dan PACF setelah dilakukan differencing pertama dan musiman lag 12.

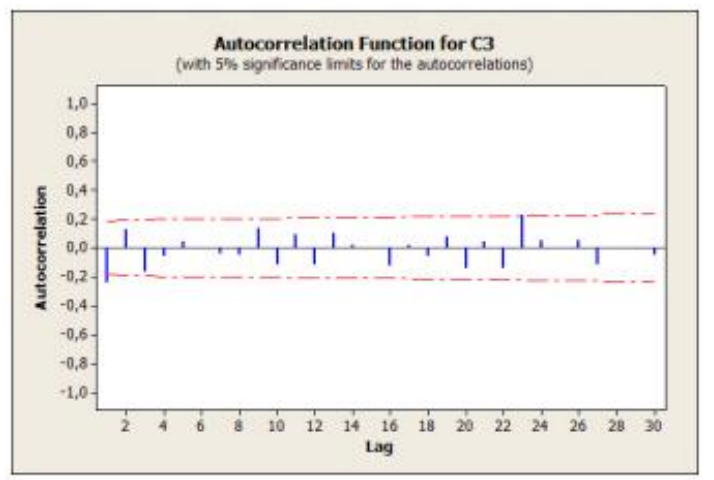

Gambar 5. Grafik ACF differencing pertama dan Lag 12

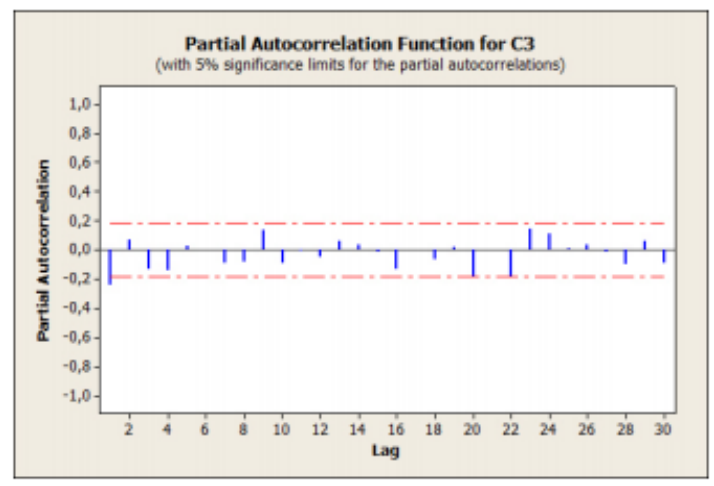

Gambar 6. Grafik PACF differencing pertama dan Lag 12

Dengan melihat bar yang melebihi garis putus-putus. pada grafik ACF terlihat bahwa pada bar pertama garis vertikal melewati garis putus-putus begitu juga dengan grafik PACF pada bar pertama garis vertikal juga melewati garis putusputus. Dengan demikian diperoleh beberapa kandidat model SARIMA data penumpang yang diperlihatkan pada Tabel 1.

Tabel 1. Calon Model SARIMA Data Penumpang dengan Metode Seasonal ARIMA

\begin{tabular}{|c|c|l|}
\hline Model & MSE & \multicolumn{1}{c|}{ Keterangan } \\
\hline ARIMA $(1,1,1)(0,1,0)^{12}$ & 101.5 & $\mathrm{AR}(1) \& \mathrm{MA}(1)$ signifikan \\
\hline ARIMA $(1,1,0)(0,1,0)^{12}$ & 101.4 & $\mathrm{AR}(1)$ signifikan \\
\hline ARIMA $(0,1,1)(0,1,0)^{12}$ & 101.0 & $\mathrm{MA}(1)$ signifikan \\
\hline
\end{tabular}

Dari tabel di atas dapat disimpukan bahwa model SARIMA yang terbaik untuk data penumpang adalah ARIMA $(1,1,1)(0,1,0)^{12}$ karena memiliki nilai MSE terkecil yaitu 101.5. Berdasarkan Gambar 7 AR(1) signifikan karena mempunyai nilai $\mathrm{p}<0.05$. Hal ini menunjukkan bahwa model dapat digunakan. 
Sehingga model Seasonal ARIMA untuk data penumpang di Bandar Udara Raja Haji Fisabilillah: $\left[1-(-0.2347 B)(1-B)(1-B)^{12}\right] X_{t}=e_{t}$ dengan model peramalannya adalah:

$$
\begin{aligned}
e_{t} & =(1-(-0.2347 B))(1-B)(1-B)^{12} X_{t} \\
& =(1+0.2347 B)\left(1-B^{12}-B+B^{13}\right) X_{t} \\
& =\left(1-B^{12}-B+0.2347 B+0.2347 B^{13}-0.2347 B^{2}+0.2347 B^{14}\right) X_{t} \\
& =\left(1-0.7653 B-0.2347 B^{2}-B^{12}+0.7653 B^{13}+0.2473 B^{14}\right) X_{t}
\end{aligned}
$$

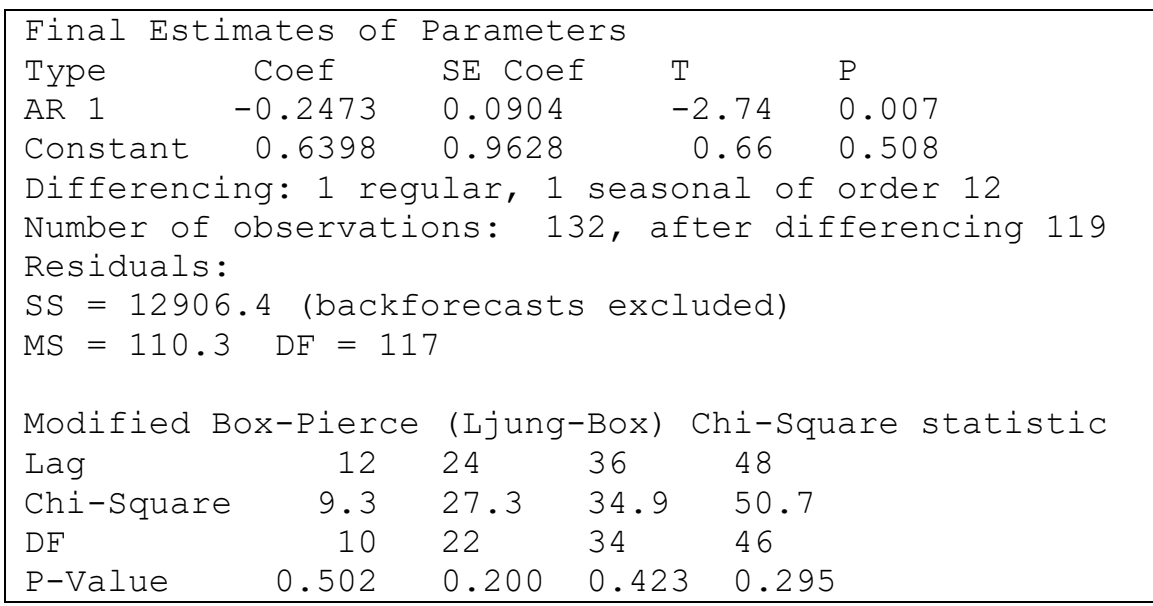

Gambar 7. Hasil analis data PACF Penumpang dengan Metode Seasonal ARIMA

Jadi:

$$
\begin{aligned}
X_{t}= & 0.7527 X_{t-1}+0.2473 X_{t-2}+X_{t-12} \\
& -0.7527 X_{t-13}-0.2473 X_{t-14}+e_{t}
\end{aligned}
$$

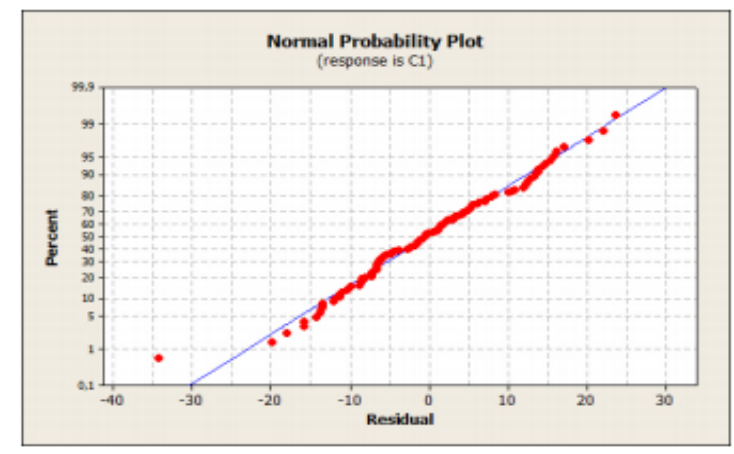

Gambar 8. Grafik Normal Probability residu dari PACF

Gambar 8 memperlihatkan residu mengikuti garis diagonal, yang berarti residu berdistribusi normal. Karena residu bersifat random dan berdistribusi normal, maka residu memenuhi asumsi white noise. Dari persamaan (2) didapatkan hasil peramalan data penumpang untuk tahun 2020 yang diberikan pada Tabel 2. 
Berikut ini adalah tabel hasil peramalan data penumpang di Bandar Udara Raja Haji Fisabilillah dengan metode SARIMA.

Tabel 2. Hasil Peramalan Penumpang Model SARIMA Tahun 2020

\begin{tabular}{|l|c|}
\hline \multicolumn{1}{|c|}{ Bulan } & Ramalan \\
\hline Januari & 427.41 \\
\hline Februari & 417.90 \\
\hline Maret & 410.27 \\
\hline April & 424.40 \\
\hline Mei & 456.20 \\
\hline Juni & 472.15 \\
\hline Juli & 630.12 \\
\hline Agustus & 608.82 \\
\hline September & 516.08 \\
\hline Oktober & 425.91 \\
\hline November & 431.76 \\
\hline Desember & 431.90 \\
\hline
\end{tabular}

Gambar 9 berikut memperlihatkan grafik perbandingan data hasil peramalan dan data asli dan plot dari hasil peramalan untuk tahun 2020 dengan data sebelumnya. Jika data hasil peramalan digabungkan dengan data sebelumnya terlihat bahwa plot data hasil peramalan mengikuti pola dari data sebelumnya.

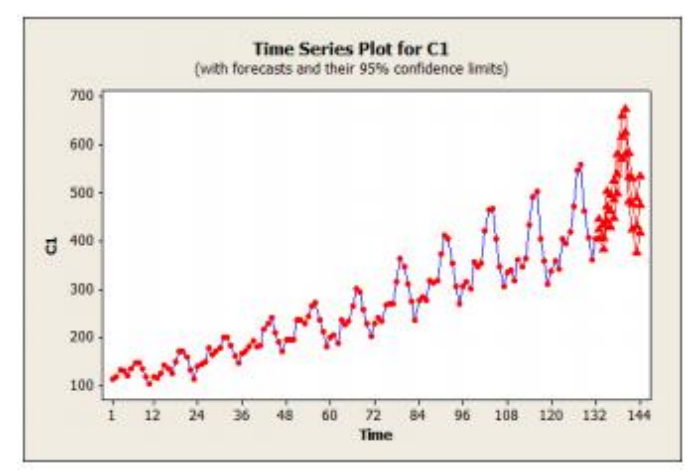

Gambar 9. Grafik Hasil Peramalan Penumpang dari PACF

\section{Kesimpulan}

Berdasarkan hasil analisa dapat diambil kesimpulan bahwa Metode SARIMA yang digunakan dalam memprediksi jumlah penumpang di Bandara Raja Haji Fisabilillah dengan data yang bersifat musiman dapat memberikan hasil peramalan yang tidak jauh berbeda dengan pola data tahun sebelumnya. 


\section{Referensi}

[1] Wahyudi, J, Arifin Zainul M dan Wicaksono D A. 2016. Kajian Kinerja Pelayanan Terminal Penumpang Domestik Bandar Udara Kelas 1 Utama Juwata Tarakan, Rekayasa Sipil Vol. 10 No. 2 ISSN: 1978-5658.

[2] Marista Putri D dan Ahyudanari E. 2017. Evaluasi Desain Terminal Penumpang Bandara New Yogyakarta International Airport, Jurnal Teknik ITS Vol. 6 No. 2 1SSN: 2337-3520 (2301-928X Print).

[3] Akbar, SE. 2018. Evaluasi Kapasitas dan Tingkat Pelayanan Terminal Penumpang Bandar Udara Ahmad Yani, Surakarta: Universitas Muhammadiyah Surakarta.

[4] Destriyani, R D. 2019. Evaluasi Terminal Penumpang Bandar Udara Raja Haji Fisabilillah Tanjung Pinang dengan Metode ARIMA dan SNI 03-7046-2004, Batam: Universitas Internasional Batam. 